\title{
Pragmatics of Spiritual Rituals for Healing in Wollo
}

\author{
Rukya Hassen* \\ Civil Service University, Addis Ababa, Ethiopia
}

Submission: November 06, 2017; Published: May 07, 2018

*Corresponding author: Rukya Hassen, Civil Service University, Addis Ababa, Ethiopia, Tel: +251913003908; Email: rukyahassens@gmail.com

\section{Abstract}

The data for the rituals of spiritual traditions were collected from key informants and through attending events. The study were conducted in Kutaber, Alasha, Sulula, \& Haik in Wollo from 2015 to 2016 G.C. Data were collected from range of live and recorded discourses from elders, youngsters, females and children from different casual and non-casual speech events. Since the ceremonies were conducted in a dark setting with too many curtains and smokes around, the researchers could not video and audio record the events. However, the full account was taken from the events and the informants. Three spiritual rituals were analyzed. Through the rituals, how the community organized their cultural performances, peaceful co-existence and harmony. Through the rituals of sprit healing, the community demonstrated that they complement each other through solidarity.

Keywords: Spiritual; Rituals; Healing; Discourse; Wollo; Ethnomethodology; Pragmatics; Interlocutors; Courpus; Ibid; Communication and Culture; Micro-cultures; Co-cultures; Spiritual healing rituals; Pledge

\section{Introduction}

Wollo is the study site where a large number of both Muslims and Christians demonstrated peaceful co-existence for a long period of time. At present, however, there are cases of challenges to such peaceful coexistence. The communication behavior of the community displays how they have developed a harmonious culture to sustain their identity.

Wollo is bounded by Tigray in the North, Gojjam in the West, Shewa in the South and Afar in the East. The capital city, Dessie, is $400 \mathrm{~km}$ away to the North of Addis Ababa. In Wollo, Muslims and Christians live together peacefully [1]. The community has a unique history of tolerance and peaceful coexistence. This community consists of a large number of Muslims and Christians. There is a thick historical record that this community exhibits a harmonious and peaceful contact and an intense sense of belongingness. The Wollo community is far more than mixed. There is a strong blood tie as there is intermarriage among Muslims and Christians. There is also cultural diffusion, and a strong sense of togetherness that has been held for generations. Many significant cultural and historical contexts tie the MuslimChristian Community to a great extent.

Wollo is a place with rich historical and cultural assets. The area is claimed to be the origin of the Amhara ethnic group [2]. According to Getachew [2], the first original home of the Amhara is Amhara Saynt. He claimed that Amhara means 'agrarian' \&
Saynt 'a place where harvest is collected' in Arabic. He further states:

Though the Agew people is mixed and so it is named as Agew Midr Begemidir, and though because of Oromo it was named Wollo later; Bete Amhara includes the areas bounded by Tigray in the North, Begemdir \& Gojjam in the West, Shewa in the south. In the middle was all the area of Bete Amhara [2].

The Amhara ethnic group lives in Lasta, Wadla Delanta, Woreilu, in large numbers, and in Dessie area, Yeju, Ambasel, Raya, Kobo, Borena and Worehimeno mixed with other ethnic groups [3]. Ethnic groups that reside in Wollo are Amhara, Agaw, Argobba, Oromo, Warra Sheikh \& Mamadoch [4].

Wollo is a place where people of different ethnic groups, beliefs and cultures are believed to have coexisted peacefully. The languages spoken in the region are Amharic, Agew, Oromo, Tigray, Afar and Argoba [2,3]. The people are known as 'Wolloyye'. The people do not want to identify themselves by their ethnic groups but by the place, 'wolloyye' (the Wollo person).

Mixed as they are, the community of Wollo demonstrated peaceful coexistence and harmonious life. They diverse but mixed society. Their cultural performances are made up of the diverse qualities. This study deals with one of their common cultural performances which is rituals of spiritual cultural 
performances. Hence, the objective of this study is to describe the discourse of pragmatics of spiritual rituals.

\section{Objectives of the Study}

The general objective of the study is to investigate pragmatics of spiritual rituals in Wollo.

Specifically, it is the objective of this study to

a. Identify pragmatics of spiritual healing rituals in Wollo.

b. How spiritual healing rituals are organized in the community of Wollo.

c. Describe discourse of healing rituals are performed.

\section{Research Methodology}

The present research calls for qualitative research design because the objective is to describe and explain pragmatics of healing rituals in Wollo. Qualitative research approach is a research method used extensively by scientists and researchers studying human behavior. A qualitative method investigates the why and how of behavior, not just what, where, and when of things that can be measured quantitatively. Qualitative research has its roots in social science and is more concerned with understanding why people behave as they do: their knowledge, attitudes, and underlying beliefs. Qualitative research is extremely useful when the issue is too complex to be answered by a simple 'yes' or 'no' hypothesis.

The purpose is to understand people's interpretations of their reality in the way it appears to them. It helps to produces in-depth and comprehensive information. It seeks to gain a complete picture of the behaviour being studied. The studies were conducted in Kutaber, Alasha, Sulula, \& Haik in Wollo. Data were collected from range of live and recorded discourses from elders, youngsters, females and children from different casual and non-casual speech events. A corpus of data were collected, transcribed and coded based on the objectives of the study. Data were collected through introspection, participant observation, in-depth interview and record of social events. For the analysis, courpus- based description, ethnomethodology and critican discourse analysis was employed. Ethnomethodology is "the use of transcripts of conversations to develop descriptions of the interlocutors' knowledge, especially of the social situation in which they interact". Ethno methodology is concerned with the discovery of the underlying processes which speakers of a language utilize to produce and interpret communicative experiences, including the un-stated assumptions that are shared knowledge. Ethno-methodologists assume that by going to cultures themselves and becoming immersed in the problems of everyday life, they could discover what constitutes cognitive reality for the members of a given culture $[5,6]$. Ethnomethodology emphasizes less on universal procedures and focus more on real contextual happenings [7]. It is the sociological partner to discourse analysis [8].

\section{Major Findings of the Study \\ Rituals}

Rituals are any customary observance or practice. It is the behaviour of human beings to perform everyday rituals. In any society rituals are the most common practices. Whether one likes it or not, one finds oneself in traditional or meaningful rituals every day. People commonly do religious or traditional rituals consciously or subconsciously. Language use reveals itself in rituals. The rituals that have been recorded live for the study are what people say and do in giving birth, visiting sick, thanks giving, congratulations, monument occasions, curses, blessings, begging, swearing, and others.

Routines and rituals are important units to control society [9]. Linguistic routines are fixed and non-flexible units of utterances which by itself fulfils communicative functions as it is per formative in nature. Understanding routines requires a shared cultural knowledge as they are metaphoric and non-literal (Ibid: 43). They include greetings, leavings, curses, condolences, prayers, and other formulaic language. Such involuntary noises as sneezes and hiccoughs might need routines as a repair of the situation (Ibid). Ritual, except for being context bounded, is made up of routines; for example, a magical incantation is a ritual where a fixed language of a spell should be uttered to affect the evil (Ibid).

Rituals contain formal communication behaviors in which both saying the wrong expression as well as not-saying the right expression could potentially cause communication breakdown and disappointment. It is one of the elements that people should know to be communicatively competent in their speech group. Because they have this grave consequence, people study the rituals purposely and use them appropriately in the way they are prescribed.

\section{Communication and culture}

Communication and culture are interconnected. Communication facilitates the creation and exchange of cultural meanings, and culture preserves communication [10]. Communication makes existence feasible [11]. Although it is difficult to split culture and communication since they are intertwined, it is possible to distinguish cultural patterns of communication in different speech communities [12].

According to Williams and Pearce [11], there are three basic components of culture. The first is language, a human communication system. The second is a story system, a sociocultural factor. The third is a set of organizations with their functions in the construction, organization, and distribution of cultural knowledge. For Dodd [13], culture is more than the three just mentioned. For him, culture is the sum of a group's beliefs, norms, activities, institutions, and communication patterns reflected in thought, speech and action. Identifying its effect on communication is one reason to study culture [13]. The people 
who have developed the culture expect the members to live by them. The expectations of cultural rudiments are expressed through language [13]. Such people are identified as members of the same group. Members of own culture are an in-group and members of other's culture are an out-group [10].

Language is a key component of cultural activity of people [14]. Every culture has its own communication system [13]. There are countercultural communication systems and common codes in a speech group that has different cultural sub-groups in it. Some groups stand opposing the dominant group and develop a countercultural communication behavior. According to Dodd [13], a common code is used to bind countercultural members. In many multicultural communities, countercultural communication is inevitable. The counterculture provides a comparatively different communication rules. Hogan-Garcia [15] defines a cultural group as follows

A culture or ethnic group (the terms can be used interchangeably) is a group in which the members generally share a complex and dynamic common cultural heritage made up of the assumptions, values, beliefs, attitudes and customs that relate to the aspects of culture... - that is, language, religion, and family life processes. Each aspect involves and functions through associated values, beliefs, assumptions, and customary behavior.

For multilingual communities, there is a need to have one common code. Countercultural group members often develop a common linguistic code, such as jargon and slang that are exclusively used by the members of the speech group [13]. The common code is known by linguists as a lingua franca. The code could be a different language or a dialect of the same language. The common code emanates from the macro culture in the same country such as the case of Amharic in Ethiopia or English in many multilingual African countries.

Related to the concept of countercultural communication are micro-culture, co-culture and subculture. Micro-culture or co-culture is a collectivity with mindful identity and grouping coexisting within the macro-culture [13]. Micro-cultures or cocultures often experience common premises regarding image, bonding, and relationship. Micro-cultures or co-cultures are assumed to coexist within a macro-culture. Micro-culture or co-culture is a subculture of the larger macro-culture that is common for the major speech community and the subgroup in the larger community. Micro-culture or co-culture is the culture of the subgroup. Subculture is a separate culture of a group. In sociology, anthropology and cultural studies, a subculture is a culture that separates a group from others within a larger culture identifying them as a separate social group.

\section{Spiritual healing rituals}

In the study area, there is a tradition of using animals for the purpose of worshiping. In most of the cases, animals are prescribed to be used as sacrifices for the chief spirit of evil by whisper of sorcerer. What the spirit wants to heal the sick person is prescribed by the witch who is assumed to know what is the unknown because either it was in the past or because it is in the future. It is believed that the sickness may be inherited or the spirit may just jump on somebody s/he likes and would not let go unless the sick person makes regular sacrifices. Many believe in the power of such spirits and the animal sacrifice to heal the sick which, of course, is caused by the whisper of the spirit. When there is a sick person who is suspected of being infected by such spirit, his family would take him/her to a knowledgeable person who would do appeal for the relief of the sick person.

Most of the time, people come to know about which of the five spirits called 'zar' or 'wukabi' is causing the affliction by asking a witch. When the witch is told about the symptoms of the sickness of the afflicted person, s/he would say 'this is the cause of the wrath of, for example, a female spirit known as 'Rahelo'. Then, the 'zar' or 'wukabi', would tell what kind of animal they should offer as sacrifice. Upon their return to their homes, the family or relative of the sick person would find a performer of the rituals in their neighborhood. They would go and make appointment for a ritual to be held. This happens if it is for the first time. If it is already practiced, they would just go and make appointment as usual.

On the date of performance, there are things that should be there for the ritual. These include a local drink as 'tela' or 'bukri', the inevitable coffee, home-made roasted bread, barley, maize, beans, and pop corn.

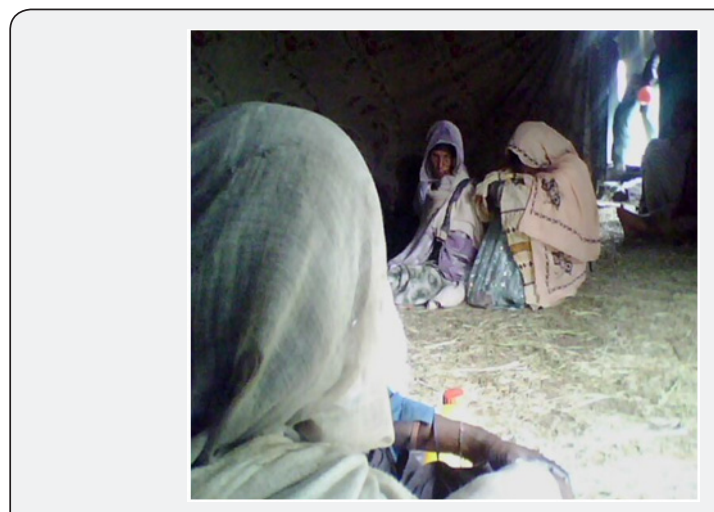

Figure 1: A Spiritual Ritual Event

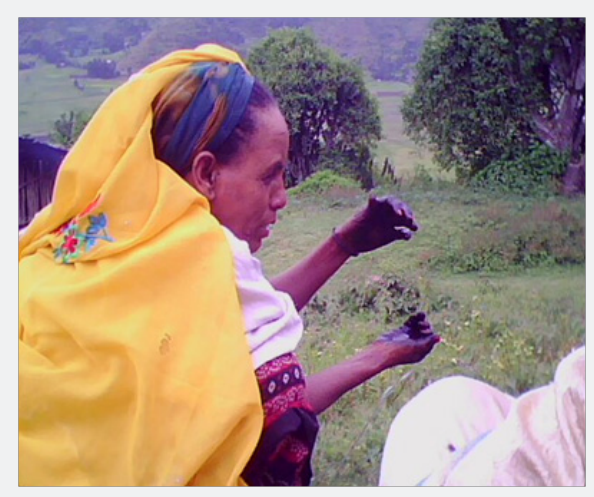

Figure 2: A Spiritual Ritual Event 
For those kinds of 'zar' or 'wukabi' rituals, the performers would also be made ready. If it is a female, she would have her hair done 'shuruba', color her hands and feet with special plants known as 'ensosla \& gushrit') (Figure 1\&2). She would get dressed in white traditional cotton dress. If it is male, he would wear clean clothes and have a clean and white 'Gabi', a local garment.

The surrounding is also made clean. Incense is burnt and grass is sprinkled on the floor. There are particularly required incenses that are used to call for and welcome the spirit. These include 'kerbe', 'ades' 'kebercho' and others.

The five major kinds of spiritual performance are called rahelo, changer, anbeso, oromo and zebenya, excluding other minor spiritual performances.

The Performance of 'Čängär Zar' 'Wukabi' (Spirit)

Čängär is assumed to be a male Zar spirit. The animals that are offered as sacrifice include one grey rooster cock, one brown rooster cock, one white and one red rooster cock or a red male sheep. The person who is possessed by a Čängär 'zar' is assumed to get sick with sharp pain on the ribs, the back and the thigh.

The animals are sacrificed in the above subscribed order each year. The first year, the grey adult rooster, the next year the white and the third year the red cock are sacrificed. Then on the fourth year, a four legged animal is required. So, instead of the fourth red adult rooster, a red male sheep is bought and presented to the possessed person to caress it. It would grow until the fourth year and the sheep is sacrificed with all the other roosters. The ritual is done on a Tuesday or Thursday in April or May. The other food and drink prepared for the ritual are served in the same way as mentioned above. At 1 PM, people are gathered and the person who leads the performance begins chanting before eating the food. The chanting goes as follows enumerating Čängär:

yäzzih 'ägär 'ädəbar qut'bu 'əndämmənäwu

yät'ena t'äbbaqiwu č’ängär bärräñawu

’əbär lay qumo ’äbet yämmiläwu

yagäru t'äbaqi č'ängär ’əndännäwu

'əsti 'äč' č'ač'suna 'ährib 'ənəbbäläwu

’ärəb robn šwami sänəbbätn ’äkbari

’äyədäläm wäy č’ängär gud yäləbbun säri

lalibäla wulo gəšän ’ädariwu

balä wärəq mäsəqäl baläqač’əl näwu

betäkrəstiyan gäbto qəne yämmiyawärawu

yä’ärəba 'äratoč wädağ č'ängär bärräñawu
How is the spirit of this country?

The guardian of health Čängär the gate,

One who says 'yes' staying at the gate keeper,

The guard of the country, how is Čägär?

Put on incense and let us invite him,

He fasts on Wednesdays and Fridays and observes Sabbath,

Is it not Čängär who does what he wants?

He spends the day in Lalibela and the night in Gishen,

He has a gold cross and a bell,

He enters church and speaks in figurative language,

The ally of the forty four covenants, Čängär, the guardian.

As explained in the above extract, the people believe that Čängär is a true follower of Christianity. The target speech group, though they are Muslims, conduct the ritual as such. The rooster would be rubbed against the back of the person just before they slaughtered. The sheep's forelegs are put on the shoulders of the person three times and his forehead rubbed against that of the sheep's forehead. The animals are then slaughtered. The blood is covered with grass. The knife is wiped with grass and they would leave the blood and the slaughtered animals alone without cutting them into pieces. While the animals are left in such a manner, the people would eat and drink. First, the food is given to the sick person then the attendants are given from each type of food.

After eating, those who are in a hurry are excused to go. Then the meat of the slaughtered animals is given to the ladies to prepare dinner. The right parts of the body are prepared for the rest of the family. On the third day, there is a closing ceremony after which the person is free to go anywhere s/he wants.

\section{'Anbesso Zar' or 'Wukabi' Performance}

The animals that are put for the sacrifice of Anbesso are one adult rooster, a white adult rooster, a red adult rooster or red male sheep. The symptoms of Anbesso's affliction are back pain with difficulty in sitting, and stomachache. As prescribed by a witch, the sacrifice is made in November or April on a Tuesday or Thursday. They make an appointment with a performer for the ritual. The family, relatives, friends and neighbors are informed of the date in advance. In the mean time, foods and drinks are prepared. It is locally known as 'feast making'. On the opening day, the leader says:
'äbet 'änbässo 'äbet 'änbässo
’əsu kitab qäri balät'oharawu
baläqäy qoti baläqet'ämawu
yäšähoču wädağ tänägagariwu
gəra qäñ təkəša yämiragät'äwu 
baläqäy korəma baläğəbmawu

’ənkətkət səbrəbr 'ärgo ’əmigäzawu

'əsu däm 'äsqämač' ğärba qomač' näwu

marəlləñ näwu ’ənği lela mən 'älnäwu

gəbr ’ənədämolla ’əyasräkäbnäwu

Oh 'Anbeso' Oh 'Anbesso',

He reads religious books and he is clean,

He is red lover and he has grass,

He is ally the Sheikhs and he is fluent,

He kicks left and right shoulder,

He is fond of red bull,

He causes stomach and back ache,

We say nothing but help us,

We are offering the food full of his desire.

Anbesso is assumed to be a Muslim. They beg him by recognizing his powers and the sacrifices they have presented. Then the performer says, "we have banned you from requiring such sacrifice for the next four years." Then sacrifices are offered from each kind of food and drink, and a portion is put aside for the third day. Then, from each kind of food and drink, a portion is sprinkled around. As they sprinkle, they say 'May you allow us live until next year. Here is your sacrifice.' Then the roasted grain (qolo) is mixed with an Ethiopian seed known as 'nug' and is given to the attendants. Then bread and coffee are served. The right side of the meat of the sacrificed animals is reserved for the sick person. Those who did not enter at the time of the ritual would not enter the house for the next three days so that the spirit would not affect them. The ritual would be repeated on the third day and that would be the end of it for the next four years.

\section{Water Therapy- '㽖 s'äbäl'}

There is a belief that some waters have magical effects to cure diseases. Water therapy is the use of water to regain health. Medical science also shares this belief but the belief on water therapy does not come from spirits or saints putting their blessings on the water. The target group believe that the therapeutic effect of particular waters come from the blessings of saints or spirits. Water could be therapeutic in the medical sense when drinking and bathing.

Water therapy has many forms. The most common forms in the target group are bathing and drinking for three, 'one seven' or 'two seven' days, to use their own expressions. 'One seven' means seven days only. 'Two seven' means fourteen days. The application of water in the treatment of different diseases has been consistently promoted by a number of people in the area.
They implement bathing, repetitive quaffing of foul, tasting, spitting on, and sprinkling water on the body and around the area where there is pain.

The belief on water therapy is very strong among the Christians. There are many well-known places of holy water (Tsebels) in many churches and they are associated with saints. Many people, including Muslims, visit them for relief from illness of all types.

The Muslims do not only go to the Christians' holy waters; they also have their own as well. Around Gerado, there is a place called Bilen where there is Muslims' holy water that is named after Sheikh Ali Jiru. It is called the sheikh Ali Jiru water. They do not call it holy water or 'tsebel'. They call it, 'Yesheikhocu wuha'the water of the Sheikh.

\section{Pledge}

Pledge which is locally known as 'səllät' is an offering of a spiritual kind. The offering is promised to God, saints or spirits. The speech community are accustomed to offering promise mostly to fast for some time, to offer animal as sacrifice, to give money, to beg, to make a feast in return to a favor by a saint. The practice is considered as a debt. When people get what they have wanted or asked for, they give offerings as promised.

A pledge of begging as offering is made to spirits. Many believe that such spiritual vowing is inherited from ancestors. When a person gets sick, he consults someone with spiritual power whether there was a history of ancestral pledge inherited. Some adherents of a spirit or saint make a festive occasion to recognize the spirit's favor.

The other unique vowing practice is that the Muslims pledge to Christian saints and the Christians to Muslims'. Many Muslims pledge to the angels, local saints and other significant personalities in Christianity. The offering is promised to buy materials such as umbrella, to give money, or to make a commemorative occasion in memory of the favor they have been given. There are Muslims who conduct such occasions in response to their answered prayers (they believe so). There are also many Christians who do the same for Muslims' saints.

\section{Conclusion}

Rituals play significant role in communication. It is one of the elements that people should know to be communicatively competent in their speech group. Because they have this grave consequence, people study the rituals purposely and use them appropriately in the way they are prescribed. Spiritual healing rituals play significant role in sustaining cultural values in Wollo. The community use the rituals for healing spirit related illnesses. There are well structured linguistics and non-linguistics aspects of pragmatics that the society use to sustain their cultural performances. The pragmatic competence of the communication system require the participants to equip themselves with appropriate knowledge and skill of the elements of the ritual 
and its performances. Theses rituals contain the values of the community. It helps them sustain their cultural values of peaceful co-existence and solidarity.

\section{References}

1. Amsalu A (1987) The Influence of Arabic on Ethiopian Languages. A Paper Presented on Afro Arab Relations Colloquium. Khartoum. In Language Miscellanea p. 34-56.

2. Getachew M (1984) Wollo: Country's Context. Nigd printing press. Addis Ababa.

3. G/Kidan W/H (1981) Historical Works of Wollo Sub Country Culture and Sport Affairs Minister Education from 1977-1981 E.C. (Unpublished). Dessie.

4. Endris M (2007) Shaykh Seid Muhammed Sadiq /1897-1977/: philological, historical \& patriotic legacy. African printing press: Adddis Ababa.

5. Burk JL, Lukens JG (1979) On the reliance of cognitive anthropology and ethno methodology. In: Handbook of Intercultural Communication. Beverly Hills: Sage Publications.

6. Wardhaugh R (1986) An Introduction to Sociolinguistics. Oxford: Blackwell.

7. Silverman D (1985) Qualitative Methodology and Sociology. Aldershot: Grower Publishing Company Limited.
8. Davies A (2007) An Introduction to Applied Linguistics: From Practice to Theory ( $2^{\text {nd }}$ edn), Edinburgh University Press, Edinburgh.

9. Saville-Troike M (1989) The Ethnography of Communication: An Introduction. Oxford: Basil Blackwell Ltd.

10. Klyukanov IE (2005) Principles of Intercultural Communication. Boston: Pearson Education, Inc.

11. Williams, Pearce (1978) The Vital Network: A Theory of Communication and Society. London: Greenwood Press, UK.

12. Condon JC , Yousef FS (1975) An Introduction to Intercultural Communication. Indianapolis: The Bobbs-Merrill Company, Inc.

13. Dodd CH (1995) Dynamics of IntercuFltural Communication. Madison: WM.C. Brown Communications, Inc.

14. Greenberg JH (1971) Language, Culture, and Communication. Stanford: Stanford University Press, USA.

15. Hogan-Garcia M (2003) The Four Skills of Cultural Diversity Competence: A Process for understanding and Practice $\left(2^{\text {nd }}\right.$ edn), Victoria: Thomson Learning Inc.

16. Dornyei Z (2007) Research Methods in Applied Linguistics: Quantitative, Qualitative and Mixed Methodologies. Oxford: Oxford University Press.

\section{Your next submission with Juniper Publishers} will reach you the below assets

- Quality Editorial service

- Swift Peer Review

- Reprints availability

- E-prints Service

- Manuscript Podcast for convenient understanding

- Global attainment for your research

- Manuscript accessibility in different formats

( Pdf, E-pub, Full Text, Audio)

- Unceasing customer service

Track the below URL for one-step submission https://juniperpublishers.com/online-submission.php 